\title{
Effects of Oxygen Partial Pressure and Laser Energy Density on the Heteroepitaxial Growth of YSZ on $\mathrm{Si}(001)$ by Pulsed Laser Deposition
}

\author{
Tomoaki YAMADA, Naoki WAKIYA, Kazuo SHINOZAKI and Nobuyasu MIZUTANI \\ Department of Metallurgy and Ceramics Science, Graduate School of Science and Engineering, Tokyo Institute of Technology, \\ 2-12-1 O-okayama, Meguro-ku, Tokyo 152-8552
}

\section{パルスレーザー蒸着法による Si(001) 上への YSZ 薄膜のへテロエピタキシャル成長に 及ぼす酸素分圧とレーザーエネルギー密度の影響 \\ 山田智明 ·脇谷尚樹 · 篠㟝和夫 ·水谷惟恭 \\ 東京工業大学大学院理工学研究科材料工学専攻, 152-8552 東京都目黒区大岡山 2-12-1}

\begin{abstract}
Yttria-stabilized zirconia (YSZ) was deposited on hydrogen-terminated $\mathrm{Si}(001)$ by pulsed laser deposition (PLD) under various oxygen pressures (about $2-2 \times 10^{-4} \mathrm{~Pa}$ ) and laser energy densities $\left(0.87-1.09 \mathrm{~J} / \mathrm{cm}^{2}\right) \mathrm{at}$ $800^{\circ} \mathrm{C}$. The effects of $\mathrm{O}_{2}$ pressure and laser energy density were found to be important to the formation of an epitaxial oxide thin film. With decreasing laser energy density, the $\mathrm{O}_{2}$ pressure required to grow epitaxial YSZ films was shifted toward the lower region. Therefore, epitaxial growth of YSZ films could be achieved at a very low pressure of $2 \times 10^{-4} \mathrm{~Pa}$ compared with the known $\mathrm{O}_{2}$ pressure region used for epitaxial growth. The roughness of surfaces was very low, within $0.18-0.26 \mathrm{~nm}$.
\end{abstract}

[Received April 21, 2000; Accepted June 21, 2000]

Key-words : Pulsed laser deposition, Epitaxy, Yttria-stabilized zirconia, Silicon, Thin film

\section{Introduction}

Metal/ferroelectric/semiconductor field-effect transistors (MFS-FETs) have been intensively studied for the coming generation's ferroelectric nonvolatile random access memory (FeRAM) and will replace the $1 \mathrm{~T}-1 \mathrm{C}$ structure's FeRAM. However it is difficult to control the interface between a $\mathrm{Si}$ wafer and a ferroelectric layer from the viewpoint of ionic diffusion and incoherence. In addition, decreasing the cell size would bring about a problem of the size effect on the properties. In order to solve these problems, it is necessary to epitaxially grow an oxide film as a buffer layer between the $\mathrm{Si}$ wafer and the ferroelectric layer. ${ }^{1)}$ The required properties of the buffer layer for MFS-FETs are as follows:

- high resistivity,

- epitaxial growth on Si for the realization of an epitaxially grown ferroelectric layer,

- prevention of ionic diffusion between $\mathrm{Si}$ and the ferroelectric layer,

- high relative dielectric constant, $\varepsilon_{\mathrm{r}}$,

- smooth surface.

Some oxides are known to grow epitaxially on $\mathrm{Si}^{2{ }^{2), 3)} \text { Yttria- }}$ stabilized zirconia (YSZ) is one of these oxides and has high chemical stability and high relative dielectric constant $\left(\varepsilon_{\mathrm{r}}=\right.$ 27). The lattice mismatch between $\mathrm{YSZ}(001)$ and $\mathrm{Si}(001)$ is $-5.34 \%$ at room temperature. YSZ films are grown epitaxially on $\mathrm{Si}(001)$ with the cube-on-cube relation (YSZ $[100] / / \mathrm{Si}[100])$ using, for example, pulsed laser deposition (PLD), 4)-8) electron-beam evaporation ${ }^{9), 10)}$ and sputtering. ${ }^{11)-13)}$ It has been reported that the $\mathrm{O}_{2}$ pressure during deposition strongly affects the epitaxy of YSZ films on $\mathrm{Si}(001) .{ }^{4), 9)}$ In $\mathrm{PLD}$, the optimum $\mathrm{O}_{2}$ pressure for epitaxial growth lies between $2.6 \times 10^{-2}$ and $9 \times 10^{-2} \mathrm{~Pa}$ at the laser energy density of $1.3 \mathrm{~J} / \mathrm{cm}^{2}$, below which, YSZ films have a preferred (111) orientation. $\left.{ }^{4}\right)$ It was also reported that the laser wavelength and repetition rate of the laser affect the orientation and the $\omega$-rocking curve full-width at half maximum (FWHM). 5) This suggests that the crystal structure of YSZ films is affected by not only the $\mathrm{O}_{2}$ pressure but also the pulsed laser condition. In PLD, the laser energy density is one of the most important parameters, whereas the relationship between the laser energy density and the crystal structure of YSZ films has not yet been clarified. The purpose of this work is to clarify the effects of $\mathrm{O}_{2}$ pressure and laser energy density on the crystal structure of YSZ films on $\mathrm{Si}(001)$.

\section{Experimental}

YSZ films were deposited on $\mathrm{Si}(001)$ by pulsed laser deposition (PLD) with a $\mathrm{KrF}$ excimer laser $(\lambda=248 \mathrm{~nm})$. The laser beam was focused on the target at an angle of $45^{\circ}$ and at a spot size of $0.09 \mathrm{~cm}^{2}$ by a fused silica lens. The laser energy density was controlled within $0.87-1.09 \mathrm{~J} / \mathrm{cm}^{2}$. The laser was fired at a repetition rate of $7 \mathrm{~Hz}$. The distance between the substrate and the target was maintained at 55 $\mathrm{mm}$. The target was rotated continuously during deposition. The YSZ target was prepared by pressing YSZ powder ( $8 \mathrm{~mol} \%$ yttria, Tosoh Corporation, Japan) and sintering for $2 \mathrm{~h}$ at $1500^{\circ} \mathrm{C}$ in air. Si substrates in size $10 \times 10 \mathrm{~mm}^{2}$ were cut from polished $\mathrm{Si}(001)$ wafers (n-type, 0.1-1.0 $\Omega$. $\mathrm{cm})$. In order to clean the Si surface, the substrates were degreased with 2-propanol and dipped in three solutions, $\mathrm{NH}_{4} \mathrm{OH}: \mathrm{H}_{2} \mathrm{O}_{2}: \mathrm{H}_{2} \mathrm{O}=1: 1: 4$ for 10 min at $80^{\circ} \mathrm{C}, \mathrm{HF}: \mathrm{H}_{2} \mathrm{O}$ $=1: 10$ for $1 \mathrm{~min}$ at room temperature and $\mathrm{HCl}: \mathrm{H}_{2} \mathrm{O}_{2}$ : $\mathrm{H}_{2} \mathrm{O}=1: 1: 4$ for $10 \mathrm{~min}$ at $80^{\circ} \mathrm{C}$. In addition, the substrates were dipped in diluted $\mathrm{HF}\left(\mathrm{HF}: \mathrm{H}_{2} \mathrm{O}=1: 10\right)$ to remove the surface oxide and to terminate the surface with hydrogen, and then placed inside the deposition chamber. The substrates were heated to $800^{\circ} \mathrm{C}$ at the base pressure of $<10^{-4} \mathrm{~Pa}$ to prevent the growth of silicon dioxide. $\mathrm{O}_{2}$ gas was introduced and was maintained at the prescribed pressure from $30 \mathrm{~s}$ after the beginning of laser pulsing. The deposition time was 30 min.

The structural properties of the films were characterized by X-ray diffraction (XRD) using $\mathrm{Cu} \mathrm{K} \alpha$ radiation operated at $40 \mathrm{kV}-45 \mathrm{~mA}$ (X'Pert-MPD $(\theta-\theta$, Open Eulerian Cradle), Phillips). The chemical composition of the film was detected using energy dispersive spectroscopy (EDS) and 
wavelength dispersive spectroscopy (WDS). The measurement of film thickness was achieved using a surface profile method (Dektak ${ }^{3}$, Sloan). The surface morphology was observed by atomic force microscopy (AFM, Nanoscope III, Digital Instruments)

\section{Result and discussion}

Figure 1 shows the change of the deposition rate with $\mathrm{O}_{2}$ pressure as a function of laser energy density. The deposition rate increased with increasing laser energy density. At the same laser energy density, below $10^{-2} \mathrm{~Pa} \mathrm{O}_{2}$, the change of the deposition rate was almost constant. However, above $10^{-2} \mathrm{~Pa} \mathrm{O}_{2}$, the deposition rate was significantly affected by $\mathrm{O}_{2}$ pressure and decreased with increasing $\mathrm{O}_{2}$ pressure.

The composition ratio of $\mathrm{Y}_{2} \mathrm{O}_{3} /\left(\mathrm{Y}_{2} \mathrm{O}_{3}+\mathrm{ZrO}_{2}\right)$ of $\mathrm{YSZ}$ films plotted against laser energy density is shown in Fig. 2 . EDS and WDS were used to determine the chemical composition. In the figure, the composition ratio of $\mathrm{Y}_{2} \mathrm{O}_{3} /\left(\mathrm{Y}_{2} \mathrm{O}_{3}+\right.$ $\mathrm{ZrO}_{2}$ ) was almost constant regardless of laser energy density.

In this work, (001)- and/or (111)-oriented YSZ films were obtained, as shown in Figs. $3(\mathrm{a})$ and $(\mathrm{b})$. Figure $4(\mathrm{a})$ shows a pole figure for $\{110\}$ planes of the (001)-oriented film, and Fig. 4(b) shows a pole figure for $\{100\}$ planes of the (111)-oriented film. In Fig. 4(a), four poles are clearly observed every $90^{\circ}$. On the other hand, Fig. 4(b) shows a ring. Therefore these figures indicate that (001)-oriented YSZ films were grown epitaxially on $\mathrm{Si}(001)$ with the cubeon-cube relation (YSZ[100]//Si[100]); however, (111)oriented YSZ films were grown without in-plane alignment.

Figure 5 shows the degree of orientation for the YSZ

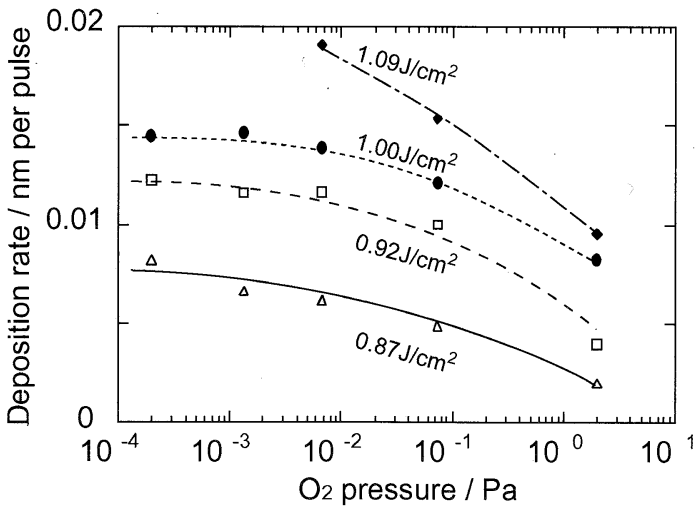

Fig. 1. Deposition rates with $\mathrm{O}_{2}$ pressure as a function of laser energy density.

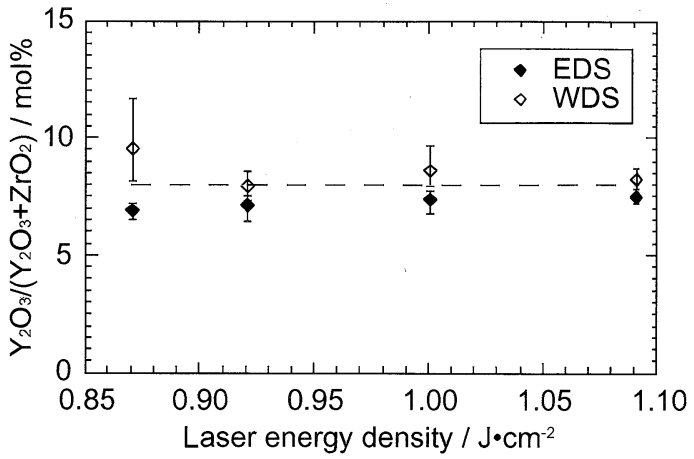

Fig. 2. Composition ratio of $\mathrm{Y}_{2} \mathrm{O}_{3} /\left(\mathrm{Y}_{2} \mathrm{O}_{3}+\mathrm{ZrO}_{2}\right)$ of $\mathrm{YSZ}$ films with laser energy density measured by EDS and WDS.
(002) peak as functions of $\mathrm{O}_{2}$ pressure and laser energy density. The degree of orientation for the YSZ(002) peak was defined according to the following equation.

It should be noted that only $(00 l)$ and $(h h h)$ peaks were observed in this work.
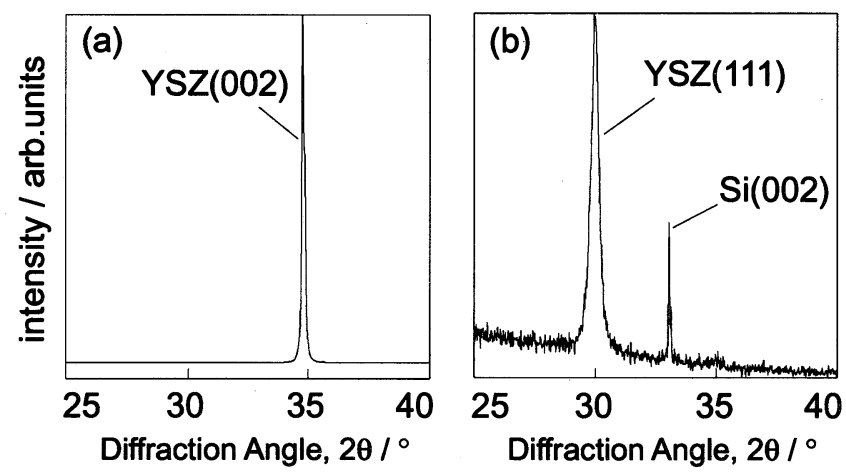

Fig. 3. $2 \theta$ scans of YSZ films: (a) preferred (001) orientation, (b) preferred (111) orientation.
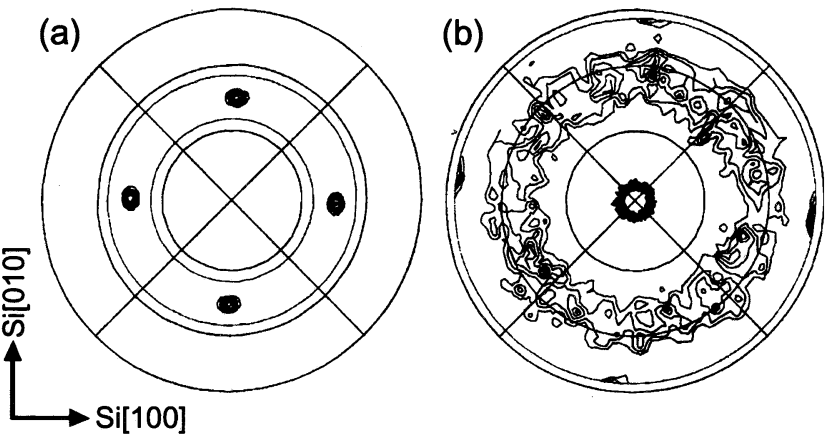

Fig. 4. X-ray pole figures of YSZ films: (a) $\{110\}$ planes of the (001)-orientated film, (b) $\{100\}$ planes of the (111)-orientated film.

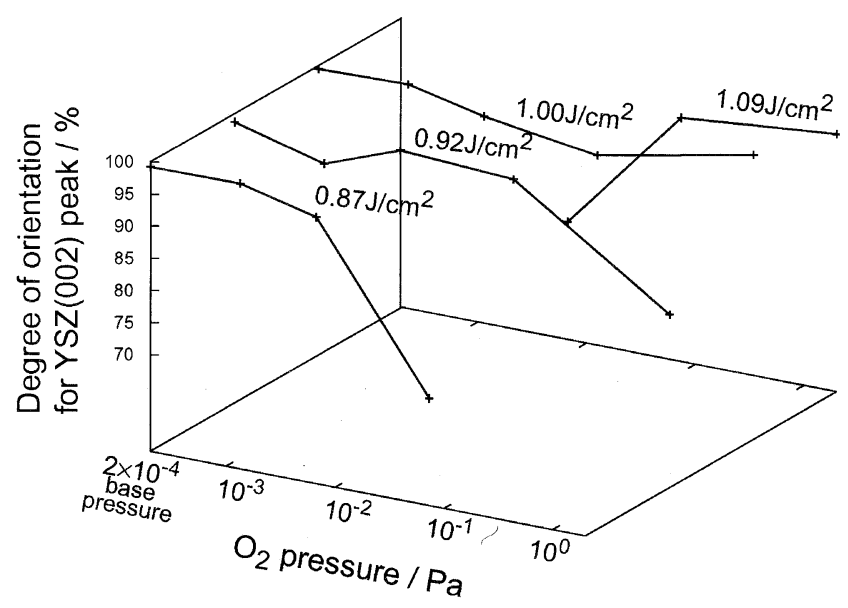

Fig. 5. Degree of orientation for YSZ (002) peak: YSZ films were deposited at $800^{\circ} \mathrm{C}$ on $\mathrm{Si}(001)$ over ranges of $\mathrm{O}_{2}$ pressure and laser energy density. $\mathrm{O}_{2}$ gas was introduced into the chamber at 1.3 $\times 10^{-3}, 6.7 \times 10^{-3}, 7.3 \times 10^{-2}$ and $2 \mathrm{~Pa}$. The base pressure was $2 \times$ $10^{-4} \mathrm{~Pa}$. The variation of laser energy density at $7 \mathrm{~Hz}$ repetition rate was $0.87,0.92,1.00$ and $1.09 \mathrm{~J} / \mathrm{cm}^{2}$, respectively. 


$$
\frac{(002)_{\text {int. }}}{(002)_{\text {int. }}+(111)_{\text {int. }}} \times 100(\%)
$$

At high laser energy density $\left(1.09 \mathrm{~J} / \mathrm{cm}^{2}\right)$, at a pressure of $>10^{-2} \mathrm{~Pa} \mathrm{O}_{2}$, YSZ films were grown with (001) orientation; below this $\mathrm{O}_{2}$ pressure, (111) orientation became strong. This result indicates that sufficient oxygen is necessary to grow YSZ films epitaxially, which almost agrees with the reported result. ${ }^{4)}$ On the other hand, at low laser energy density $\left(0.87 \mathrm{~J} / \mathrm{cm}^{2}\right)$, the optimum $\mathrm{O}_{2}$ pressure for growth with $(001)$ orientation was shifted to the lower $\mathrm{O}_{2}$ pressure region. This finding shows that it is possible to realize epitaxial growth of YSZ film even in $2 \times 10^{-4} \mathrm{~Pa}$ (i.e., base pressure). The reason for this was not completely clarified. However, the following two suggestions were made.

(1) The deposition rate increases with increasing laser energy density, as shown in Fig. 1. This means that the number of ablated species per pulse changes with laser energy density. Based on this point, it would be considered that the amount of $\mathrm{O}_{2}$ gas necessary for epitaxial growth of YSZ films changes relative to the number of ablated species.

(2) Generally, the kinetic energy of species arriving at the substrate changes with distance between the substrate and the edge of the plume. ${ }^{14), 15)}$ This distance increases with decreasing laser energy density and increasing $\mathrm{O}_{2}$ pressure. Therefore, from this viewpoint, it would be considered that the $\mathrm{O}_{2}$ pressure necessary for epitaxial growth of YSZ films changes with the laser energy density in order to keep the kinetic energy of arriving species at an optimum level.

The AFM images of YSZ films deposited in $2 \times 10^{-4} \mathrm{~Pa}$ (i.e., base pressure) and $2 \mathrm{PaO}_{2}$ are shown in Figs. 6 (a) and (b), respectively. These films have the same thickness of $150 \mathrm{~nm}$. Both surfaces were very smooth, and roughness was within $0.183-0.255 \mathrm{~nm}$ over a $1 \mu \mathrm{m} \times 1 \mu \mathrm{m}$ area. Moreover, these images indicate that the surface morphology of the YSZ film grown at a base pressure is somewhat porous compared with that grown in $2 \mathrm{~Pa} \mathrm{O}_{2}$. This suggests that the porous morphology is caused by oxygen defects (such as $V_{0}^{\circ}$ ) in the YSZ film.

\section{Conclusion}

The change of the crystal structure of YSZ films on $\mathrm{Si}$ (001) as functions of $\mathrm{O}_{2}$ pressure and laser energy density in PLD was studied. The chemical composition was almost independent of the laser energy density. It was found that the optimum $\mathrm{O}_{2}$ pressure for epitaxial growth of YSZ films decreased with decreasing laser energy density. In particular, it is possible to realize epitaxial growth even at a base pressure of $2 \times 10^{-4} \mathrm{~Pa}$. The surface morphology of YSZ films was very smooth regardless of $\mathrm{O}_{2}$ pressure during deposition; however, the surface of the YSZ film grown at low $\mathrm{O}_{2}$ pressure was somewhat porous compared with that grown at high $\mathrm{O}_{2}$ pressure.

Acknowledgements This work was supported by the special coordination fund "Frontier Ceramics" from the Science and Technology Agency of Japan and Research Foundation for Material Science.

\section{References}

1) M. Suzuki, J. Ceram. Soc. Japan, 103, 1099-111.(1995) [in Japanese].

2) E. J. Tarsa, K. L. McCormick and J. S. Speck, Mater. Res. Soc. Symp. Proc., 341, 73-85 (1994). (a)

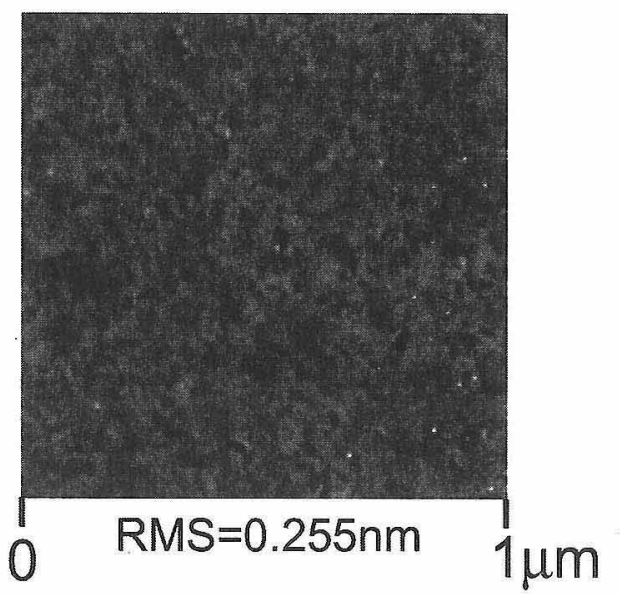

(b)

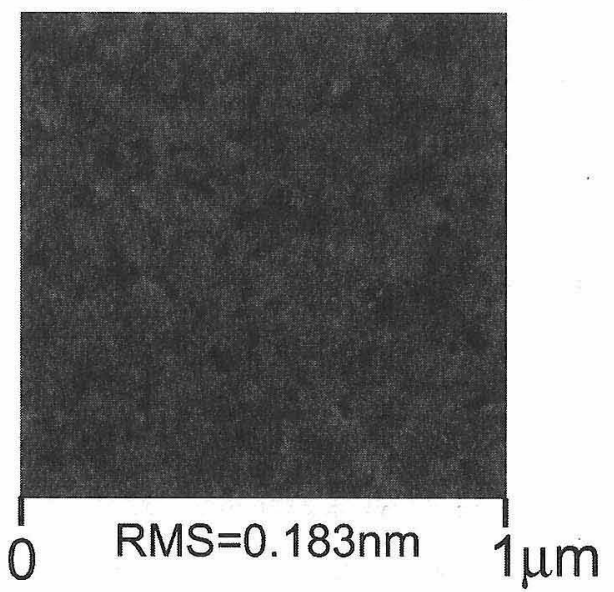

Fig. 6. AFM images of $\mathrm{YSZ}$ films over a $1 \times 1 \mu \mathrm{m}$ area: (a) at 0.87 $\mathrm{J} / \mathrm{cm}^{2}$ in base pressure $\left(2 \times 10^{-4} \mathrm{~Pa}\right)$. (b) at $0.92 \mathrm{~J} / \mathrm{cm}^{2}$ in $2 \mathrm{PaO}_{2}$.

3) M. Suzuki and T. Ami, Mater. Sci. Eng., B41, 166-73 (1996).

4) D. K. Fork, D. B. Fenner, G. A. N. Connel, J. M. Phillips and T. H. Geballe, Appl. Phys. Lett., 57, 1137-39 (1990).

5) R. Aguiar, V. Trtik, F. Sánchez, C. Ferrater and M. Varela, Thin Solid Films, 304, 225-28 (1997).

6) D. B. Fenner, D. K. Fork, G. A. N. Connel, J. B. Boyce, F. A. Ponce, J. C. Tramontana, A. M. Viano and T. H. Geballe, Mat. Res. Soc. Symp. Proc., 191, 187-92 (1990).

7) R. Haakenaasen, D. K. Fork and J. A. Golovchenko, Appl. Phys. Lett., 64, 1573-75 (1994).

8) R. D. Vispute, S. M. Kanetkar, S. B. Ogale, K. C. Rajkumar, A. Madhukar, N. Parikh and B. Patnaik, Physica C, 199, 59-64 (1992).

9) T. Hirai, K. Teramoto, H. Koike, K. Nagashima and Y. Tarui, Jpn. J. Appl. Phys., 36, 5253-58 (1997).

10) H. Fukumoto, T. Imura and Y. Osaka, Jpn. J. Appl. Phys., 27, L1404-05 (1988)

11) S. Horita, T. Tajima, M. Murakawa, T. Fujiyama and T. Hata, Thin Solid Films, 229, 17-23 (1993).

12) W. C. Tsai and T. Y. Tseng, Thin Solid Films, 306, 86-91 (1997).

13) P. Legagnuex, G. Garry, D. Dieumegard, C. Schwebel, C. Pellet, G. Gautherin and J. Siejka, Appl. Phys. Lett., 53, 1506-08 (1988)

14) D. B. Geohegan, Appl. Phys. Lett., 60, 2732-34 (1992).

15) A. Eulenburg, E. J.Romans, Y. C. Fan and C. M. Pegrum, Physica C, 312, 91-104 (1999). 